\title{
Autism Spectrum Disorder and the Gut Microbiota in Children: A Systematic Review
}

\author{
Navya Bezawada a Tze Hui Phang ${ }^{b}$ Georgina L. Hold ${ }^{c}$ Richard Hansen ${ }^{d}$ \\ ${ }^{a}$ Aberdeen Royal Infirmary, NHS Grampian, Aberdeen, UK; ${ }^{b}$ Royal Cornhill Hospital, NHS Grampian, Aberdeen, UK; \\ 'Microbiome Research Centre, St George and Sutherland Clinical School, University of New South Wales, Sydney,

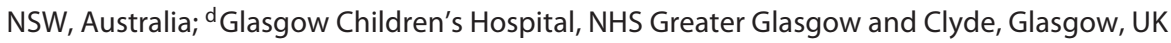

\section{Keywords}

Autism spectrum disorder · Gastrointestinal · Gut ·

Microbiota - Microbiome

\begin{abstract}
Introduction: Differences in microbiota composition in children with autism spectrum disorder (ASD) compared to unaffected siblings and healthy controls have been reported in various studies. This study aims to systematically review the existing literature concerning the role of the gut microbiota in ASD. Methods: An extensive literature search was conducted using MEDLINE and EMBASE databases to identify studies (January 1966 through July 2019). Results: A total of 28 papers were included. The studies ranged from 12 to 104 participants who were aged between 2 and 18 years from various geographical areas. Majority of studies included faecal samples; however, 4 studies examined mucosal biopsies from different sites. The heterogeneity in ASD diagnostic methodology, gut site sampled and laboratory methods used made meta-analysis inappropriate. Species reported to be significantly higher in abundance in autistic children included Clostridium, Sutterella, Desulfovibrio and Lactobacillus. The findings are however inconsistent across studies. In addition, potential confounding effects of antimicrobial use, gastrointestinal symptoms and diet on the gut microbiota are unclear
\end{abstract}

due to generally poor assessment of these factors. Conclusion: It is clear that the gut microbiota is altered in ASD, although further exploration is needed on whether this is a cause or an effect of the condition.

(c) 2020 S. Karger AG, Basel

\section{Introduction}

Growing evidence suggests that the gut microbiota has a role in the pathophysiology of autism spectrum disorder (ASD) [1]. Differences in composition of the gastrointestinal (GI) microbiota in children with ASD compared to unaffected siblings and/or healthy unrelated controls have been reported in various studies. The rates of diagnosis of ASD have increased dramatically in the past few decades [2]. Although changes to diagnostic criteria and greater awareness of the condition may be contributing to the rise, it is thought that environmental factors are also important [3]. Non-genetic risk factors, including maternal and pregnancy-related factors such as intrauterine infections and exposure to medications have gained interest as ASD incidence has continued to increase at a rate that cannot be explained by genetics [4]. In addition, there is an increasing interest in the gut microbiota in relation to ASD [1]. karger@karger.com

(c) 2020 S. Karger AG, Basel

www.karger.com/anm

Karger ${ }^{\prime}=$
Dr. Richard Hansen

Department of Paediatric Gastroenterology

Hepatology and Nutrition, Glasgow Children's Hospital

1345 Govan Road, Glasgow G51 4TF (UK)

E-Mail richard.hansen@ nhs.net 
The GI tract is home to one of the most complex ecosystems and contains around 100 trillion microbes [5]. "Microbiota" is a collective term for this microbial community which includes bacteria, archaea, eukaryotes and viruses. There is a degree of variation in the adult composition of gut microbiota and this can be influenced by diet, antibiotic use, lifestyle and genetics $[5,6]$. The gut microbiota is crucial for health in humans, with several important metabolic, protective and trophic functions and has often been referred to as the "forgotten organ" in the literature [7]. With such an impressive metabolic capacity and contribution to host health, it is no surprise, that the gut microbiota has also been implicated in disease. Characterising and understanding the gut microbiota in health and disease is a promising avenue that may lead to therapeutic benefits through its manipulation via so-called microbial therapeutics.

Changes in the gut microbiota seen in ASD may have a causative role and perpetuate GI symptoms or may simply be a confounder driven by dietary restriction. Children with autism often suffer from a range of GI symptoms, including diarrhoea, abdominal pain, constipation and gastroesophageal reflux. Estimates of the prevalence of such symptoms vary from 9 to $91 \%$ across studies [8]. A meta-analysis by McElhanon et al. [9] concluded that there was a three-fold higher risk of GI symptoms in children with ASD than in those without. Recent studies have suggested that alterations in the gut microbiota composition in children with ASD may contribute to both GI and neurological symptoms. Findings appear to be inconsistent across studies. If the gut microbiota plays a role in pathophysiology, there may be scope for novel treatment through its manipulation by microbial therapeutics [10-13]. The aim of this article is to systematically review the existing literature to evaluate variations in the gut microbiota and understand its significance in ASD.

\section{Methods}

Search Strategy and Selection Criteria

An extensive literature search was conducted using MEDLINE and EMBASE databases by 2 independent researchers (N.B. and G.L.H.). All studies published between 1966 and July 2019 were included. The following Medical Subject Heading [MeSH] terms were used, which included both the root term and text word: GI; gut; microbiota; autism; and ASD. The studies were evaluated for sample size, age range of children included, study methodology and composition of the gut microbiota. Manual searching of reference lists from potentially relevant articles was also undertaken to identify additional studies.

ASD and Gut Microbiota
Types of Studies

Randomised controlled trials, cohort studies and observational studies were included. Studies which reported duplicate results were excluded. Those where data could not be extracted were also excluded.

\section{Inclusion Criteria}

Studies were included if they compared the intestinal microbiota analysis of autistic children with those of healthy children and provided information on specific bacterial taxa.

\section{Exclusion Criteria}

Studies were excluded if they did not report on patterns of individual bacterial taxa differences. General reviews, studies based on adult subjects or animal models and in vitro studies were also excluded, along with conference abstracts and texts not in English. Clinical trials with an intervention were not included, except if the microbiota was assessed in both groups at baseline before intervention. Solely culture-based studies were excluded from this review. We also excluded case reports and studies of fewer than 12 patients.

\section{Quality Assessment}

The Newcastle and Ottawa scale for case-control studies was used to assess the quality of the studies and a quality score [1-9] was allocated to each [14]. Data collection and quality assessment were conducted independently by 2 researchers (N.B. and T.H.P.). Any disagreements were resolved through discussion until a consensus was reached.

\section{Results}

The initial search identified 898 records from MEDLINE and EMBASE. 595 articles remained following removal of duplicates. Of these, 61 studies were identified for full text eligibility after title and abstract screening. After full text screening, 26 studies were included in the review. Manual searching identified 2 further eligible articles, and therefore a total of 28 papers were included in the review (Fig. 1).

\section{Quality Assessment}

The quality scores of the 28 studies were assessed according to the Newcastle-Ottawa Scale and given a score (Table 1).

\section{Study Characteristics}

Among the 28 studies, 19 studied the difference between ASD and unaffected, unrelated children [15-33], 4 studies looked at the difference between ASD and unaffected siblings [34-36] or blood relatives [37] and 5 studies considered all 3 groups [38-42] (Table 2). The number of enrolled patients in a single study ranged from 12 to 104 participants and all were aged between 2 and 18 years. 
Fig. 1. PRISMA flow diagram for selection of published articles for systematic review.

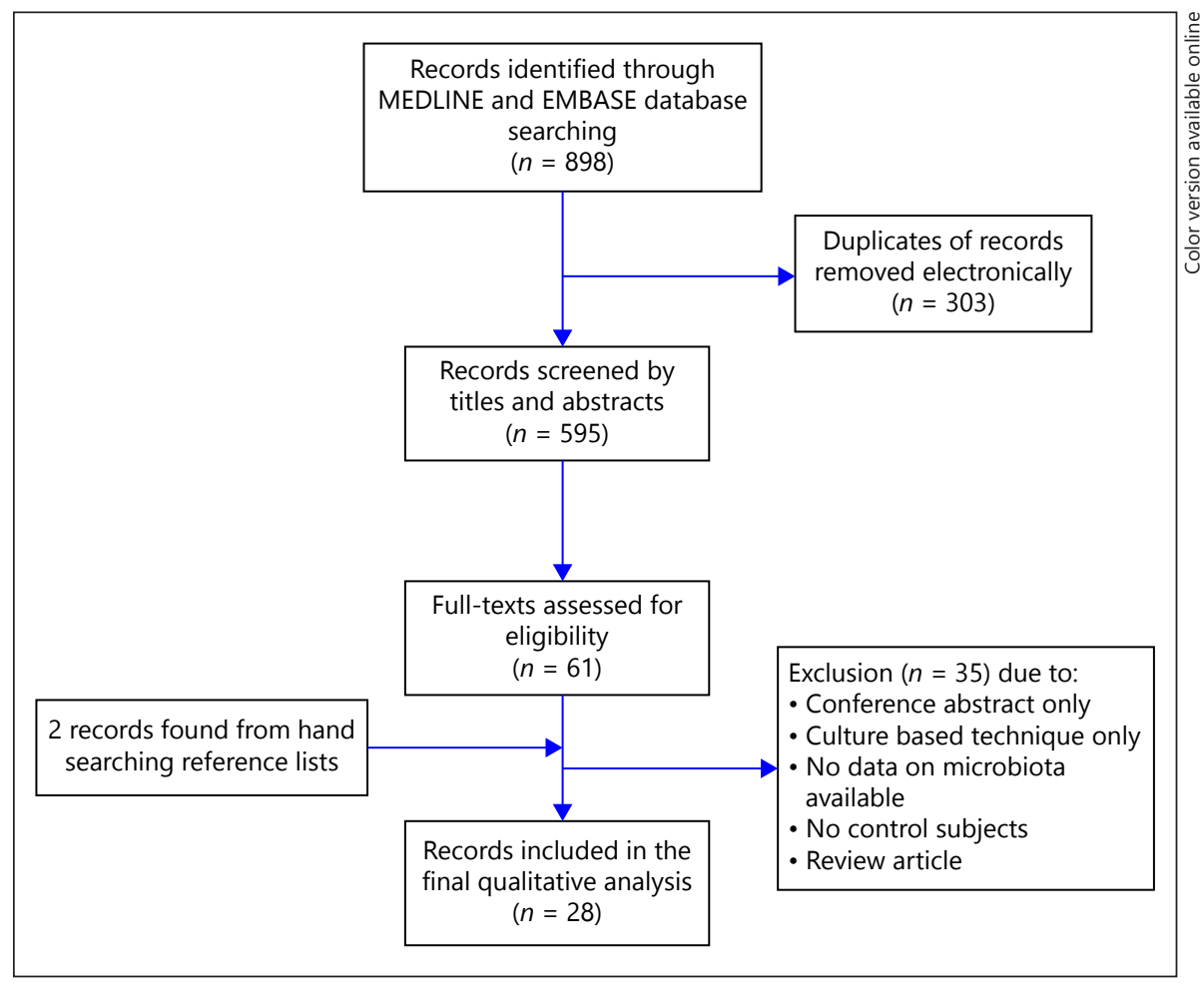

Of the included studies, the majority $(n=11)$ were from the United States, 6 from Europe [15, 20, 22, 35, 39, 42] and 3 from Australia [34, 40, 41]. The remaining 8 studies were from Asia [30, 37]. Study design including sampling strategies and microbiome analysis differed between studies. Twenty-four studies assessed faecal samples and 4 used mucosal biopsies (Table 2). Biopsy site varied for mucosa-based studies: 2 sampled ileum and caecum [21, 31], 1 sampled duodenum [17], and 1 sampled rectum [18]. The methods of collection of faecal samples also varied: from a single sample; 3 separate samples; cumulative samples over $48 \mathrm{~h}$; freshly evacuated faeces; and faecal samples following an overnight fast. In 4 studies, microbial analysis was conducted using quantitative real-time amplification of bacterial DNA (qPCR), 4 used both qPCR and 16S rRNA sequencing techniques, one study used fluorescent in-situ hybridisation and the majority (18 studies) solely used $16 \mathrm{~S}$ rRNA sequencing. One study used shotgun metagenomic sequencing [28].

\section{Criteria Used for the Definition of ASD}

The majority of studies referred to the Diagnostic and Statistical Manual of Mental Disorders, editions IV or V $[43,44]$ for the diagnosis of ASD. Other diagnostic tools were also used including Autism Diagnostic InterviewRevised [45], Autistic Diagnostic Observation Schedule
[46], Childhood Autism Rating Scale [47], Pervasive Developmental Disorders Autism Society Japan Rating Scale [48], Modified Checklist for Autism in Toddlers [49], Autism Treatment Evaluation Checklist [50], Pervasive Developmental Disorder Behaviour Inventory [51], INCLEN Diagnostic Tool for ASD [52], Indian Scale for Assessment of Autism [53] and ICD-10 [54]. Some studies simply stated that the formal diagnosis was made by a psychiatrist, psychologist or a multidisciplinary team through history and observation. In one study, families were recruited through a registry called the Simons Simplex Community through the Interactive Autism Network [36]. As ASD is an umbrella term, some studies specified certain subtypes of children in their ASD groups, for example, Asperger's syndrome and pervasive developmental disorder not otherwise specified. For control patients, numerous studies did not specifically exclude behavioural and developmental characteristics of ASD to ensure they were truly unaffected controls.

The heterogeneity in methodology within the included studies, specifically the diagnosis of ASD; gut site sampled; and laboratory methods used made meta-analysis inappropriate within this systematic review, and hence it has not been attempted.
18

Ann Nutr Metab 2020;76:16-29 DOI: $10.1159 / 000505363$
Bezawada/Phang/Hold/Hansen 
Table 1. Newcastle-Ottawa Scale quality assessment of included studies, by the year of publication

\begin{tabular}{|c|c|c|c|c|c|c|c|c|c|c|}
\hline \multirow[t]{2}{*}{ Study } & \multirow[t]{2}{*}{ Year } & \multicolumn{4}{|c|}{ Selection } & \multirow{2}{*}{$\frac{\text { Comparability }}{\text { Q5 }}$} & \multicolumn{3}{|c|}{ Exposure } & \multirow[t]{2}{*}{ Score } \\
\hline & & Q1 & Q2 & Q3 & Q4 & & Q6 & Q7 & Q8 & \\
\hline Song et al. [19] & 2004 & - & - & - & - & ** & - & - & - & 2 \\
\hline Parracho et al. [42] & 2005 & - & _- & _- & - & ** & _- & * & _- & 3 \\
\hline Finegold et al. [38] & 2010 & * & - & - & * & ** & - & - & - & 4 \\
\hline Wang et al. [40] & 2011 & * & _- & * & * & - & - & * & * & 5 \\
\hline Williams et al. [31] & 2011 & * & * & * & * & ** & - & * & - & 7 \\
\hline Gondalia et al. [34] & 2012 & - & $*$ & $*$ & - & $* *$ & - & * & - & 5 \\
\hline Williams et al. [21] & 2012 & * & * & * & * & ** & - & * & - & 7 \\
\hline De Angelis et al. [35] & 2013 & * & * & * & - & ** & - & * & - & 6 \\
\hline Kang et al. [16] & 2013 & * & - & - & - & ** & - & * & - & 4 \\
\hline Wang et al. [41] & 2013 & * & - & * & $*$ & - & - & * & * & 5 \\
\hline Tomova et al. [39] & 2014 & * & * & * & - & $*$ & - & * & - & 5 \\
\hline Son et al. [36] & 2015 & - & * & - & $*$ & ** & - & * & - & 5 \\
\hline Inoue et al. [30] & 2016 & * & * & - & * & ** & - & - & - & 5 \\
\hline Kushak et al. [17] & 2017 & * & - & - & - & - & - & - & - & 1 \\
\hline Luna et al. [18] & 2017 & * & * & * & * & ** & - & * & * & 8 \\
\hline Strati et al. [20] & 2017 & * & * & - & - & ** & - & * & - & 5 \\
\hline Berding et al. [29] & 2018 & - & * & * & - & ** & - & * & - & 5 \\
\hline Coretti et al. [22] & 2018 & * & * & * & - & * & - & * & - & 5 \\
\hline Kang et al. [32] & 2018 & * & * & - & - & $*$ & - & * & - & 4 \\
\hline Pulikkan et al. [37] & 2018 & * & - & * & * & ** & - & * & - & 6 \\
\hline Rose et al. [33] & 2018 & * & * & - & * & $* *$ & - & * & - & 6 \\
\hline Zhang et al. [25] & 2018 & * & * & * & * & * & - & * & - & 6 \\
\hline Li et al. [26] & 2019 & * & * & * & - & - & - & * & - & 4 \\
\hline Liu et al. [23] & 2019 & * & * & * & * & ** & - & * & - & 7 \\
\hline Ma et al. [24] & 2019 & $*$ & * & * & * & ** & - & * & - & 7 \\
\hline Plaza-Diaz et al. [15] & 2019 & * & * & * & * & $* *$ & - & * & - & 7 \\
\hline Wang et al. [28] & 2019 & - & * & * & - & - & - & * & - & 5 \\
\hline Zhai et al. [27] & 2019 & * & * & * & * & $* *$ & - & * & - & 7 \\
\hline
\end{tabular}

The Newcastle and Ottawa scale for case-control studies was used to assess the quality of the studies across 3 domains: selection, comparability and exposure. A quality score (0-9) is given based on the number of stars awarded; the highest quality studies are awarded up to nine stars. Selection contains 4 criteria: (Q1) is the definition adequate? (Q2) representativeness of the cases, (Q3) selection of controls, (Q4) definition of controls; comparability means comparability of cases and controls on the design or analysis (Q5, maximum 2 stars); exposure contains 3 criteria: (Q6) ascertainment of exposure, (Q7) same method ascertainment of cases and controls, (Q8) nonresponse rate. ${ }^{*}$ Represents 1 quality score.

\section{Factors Affecting Gut Microbiota}

Antibiotic Usage across Studies

Due to the dramatic impact of antibiotics on the gut microbiota [55] antibiotic usage was specifically interrogated. Reported antibiotic use by participants varied across studies (Table 2). More than half of the studies excluded subjects who reported the use of any antibiotics prior to sample collection. The duration of not using antibiotics ranged from 15 days to 3 months. The majority used 1 month as a cut-off. Eight studies did not address antibiotic use $[15,17,19,21,25,28,39,41]$. The 3 remaining studies did not exclude participants based on antibiot- ics but did collect data [31, 40, 42]. Parracho et al. [42] was the only paper to report on the effect of antibiotics, finding no relationship between exposure and the microbiota.

\section{GI Symptoms and Microbiota in ASD}

The vast majority of studies considered and collected information on GI symptoms. In most cases, parents or carers were asked to complete questionnaires (Table 2). Only a few studies specified a standardised assessment such as ROME III [56] or IV criteria [57], the 6 item GI Severity Index [58] and the CHARGE GI history survey [59]. Two studies excluded all subjects with gut problems 
Table 2. Characteristics and methodology of included studies

\begin{tabular}{|c|c|c|c|c|c|c|c|c|}
\hline \multirow{2}{*}{$\begin{array}{l}\text { Study by year of } \\
\text { publication, Country }\end{array}$} & \multirow[t]{2}{*}{ ASD } & \multicolumn{2}{|l|}{ Control } & \multirow[t]{2}{*}{ Age, years } & \multirow[t]{2}{*}{ ASD diagnosis } & \multirow{2}{*}{$\begin{array}{l}\text { Assessment of } \\
\text { GI symptoms }\end{array}$} & \multirow[t]{2}{*}{ Assessment of diet } & \multirow{2}{*}{$\begin{array}{l}\text { Assessment } \\
\text { of antibiotics }\end{array}$} \\
\hline & & $\begin{array}{l}\text { unaffected } \\
\text { siblings }\end{array}$ & $\begin{array}{l}\text { unrelated } \\
\text { children }\end{array}$ & & & & & \\
\hline \multicolumn{9}{|c|}{ Studies using faeces samples } \\
\hline $\begin{array}{l}\text { Song et al. [19], } \\
2004 \text {, USA }\end{array}$ & 15 & - & 8 & Not reported & No comment & No comment & No comment & No comment \\
\hline $\begin{array}{l}\text { Parracho et al. [42], } \\
\text { 2005, UK }\end{array}$ & 58 & 12 & 10 & $2-16$ & No comment & Questionnaire & Questionnaire & Questionnaire \\
\hline $\begin{array}{l}\text { Finegold et al. [64], } \\
\text { 2010, USA }\end{array}$ & 33 & 7 & 8 & $2-13$ & $\begin{array}{l}\text { Paediatrician } \\
\text { evaluation, } \\
\text { validated by } \\
\text { study author }\end{array}$ & $\begin{array}{l}\text { Assessed but details } \\
\text { not provided }\end{array}$ & $\begin{array}{l}\text { Not assessed but } \\
\text { addressed that some } \\
\text { children had specific } \\
\text { diets and the effect } \\
\text { of diet could not be } \\
\text { controlled in the study }\end{array}$ & $\begin{array}{l}\text { No antibiotics } \\
\text { for } 1 \text { month }\end{array}$ \\
\hline $\begin{array}{l}\text { Wang et al. [40], } \\
\text { 2011, Australia }\end{array}$ & 23 & 22 & 9 & $3-18$ & $\begin{array}{l}\text { CARS and/or } \\
\text { DSM-IV }\end{array}$ & FGID questionnaire & $\begin{array}{l}\text { Dietary data } \\
\text { presented but unclear } \\
\text { how ascertained }\end{array}$ & Questionnaire \\
\hline $\begin{array}{l}\text { Gondalia et al. [34], } \\
\text { 2012, Australia }\end{array}$ & 51 & 53 & - & $2-12$ & $\begin{array}{l}\text { Psychiatrist or } \\
\text { psychologist } \\
\text { evaluation } \\
\text { using CARS }\end{array}$ & Questionnaire & No comment & $\begin{array}{l}\text { No antibiotics } \\
\text { or antifungals } \\
\text { for } 15 \text { days }\end{array}$ \\
\hline $\begin{array}{l}\text { De Angelis et al. [35], } \\
\text { 2013, Italy }\end{array}$ & 20 & 10 & - & $4-10$ & $\begin{array}{l}\text { DSM-IV-TR } \\
\text { to categorise } \\
\text { PDD-NOS } \\
\text { and ASD ADI-R, } \\
\text { ADOS and CARS }\end{array}$ & $\begin{array}{l}\text { Excluded children } \\
\text { with chronic diarrhoea, } \\
\text { constipation, gas, } \\
\text { heartburn, bloating }\end{array}$ & Not assessed & $\begin{array}{l}\text { No antibiotics } \\
\text { for } 1 \text { month }\end{array}$ \\
\hline $\begin{array}{l}\text { Kang et al. [16], } \\
2013 \text {, USA }\end{array}$ & 20 & - & 20 & $3-16$ & $\begin{array}{l}\text { ADI-R, ADOS, } \\
\text { ATEC and } \\
\text { PDD-BI }\end{array}$ & $\begin{array}{l}\text { Modified GSI } \\
\text { questionnaire }\end{array}$ & $\begin{array}{l}\text { Recording of } \\
\text { GF/CF diet, } \\
\text { probiotics use, } \\
\text { seafood consumption, } \\
\text { and usage of nutrient } \\
\text { supplements }\end{array}$ & $\begin{array}{l}\text { No antibiotics } \\
\text { or antifungals } \\
\text { for } 1 \text { month }\end{array}$ \\
\hline $\begin{array}{l}\text { Wang et al. [41], } \\
\text { 2013, Australia }\end{array}$ & 23 & 22 & 9 & $3-18$ & $\begin{array}{l}\text { CARS and/or } \\
\text { the DSM-IV }\end{array}$ & FGID questionnaire & No comment & No comment \\
\hline $\begin{array}{l}\text { Son et al. [36], } \\
2015 \text {, USA }\end{array}$ & 59 & 44 & - & $7-14$ & $\begin{array}{l}\text { Recruited via a } \\
\text { registry called } \\
\text { the Simons Simplex } \\
\text { Community through } \\
\text { the Interactive } \\
\text { Autism Network }\end{array}$ & $\begin{array}{l}\text { Pediatric Rome III } \\
\text { questionnaire }\end{array}$ & $\begin{array}{l}\text { Daily dietary } \\
\text { intake recorded }\end{array}$ & $\begin{array}{l}\text { No antibiotics } \\
\text { for } 1 \text { month }\end{array}$ \\
\hline $\begin{array}{l}\text { Tomova et al. [39], } \\
\text { 2015, Slovakia }\end{array}$ & 10 & 9 & 10 & $4-12$ & $\begin{array}{l}\text { ICD- } 10 \text { by clinical } \\
\text { psychologist and } \\
\text { child psychiatrist } \\
\text { Additional CARS } \\
\text { and ADI }\end{array}$ & Questionnaire & No comment & No comment \\
\hline $\begin{array}{l}\text { Inoue et al. [30], } \\
\text { 2016, Japan }\end{array}$ & 6 & - & 6 & $3-5$ & $\begin{array}{l}\text { DSM-V, PARS } \\
\text { and M-CHAT }\end{array}$ & $\begin{array}{l}\text { No infant had a } \\
\text { considerable gut } \\
\text { disorder }\end{array}$ & No comment & $\begin{array}{l}\text { No antibiotics } \\
\text { for } 1 \text { month }\end{array}$ \\
\hline $\begin{array}{l}\text { Strati et al. [20], } \\
\text { 2017, Italy }\end{array}$ & 40 & - & 40 & $3-17$ & $\begin{array}{l}\text { DSM-V, ADOS, } \\
\text { CARS and Autism } \\
\text { Behaviour Checklist }\end{array}$ & $\begin{array}{l}\text { Constipation } \\
\text { assessed }\end{array}$ & $\begin{array}{l}\text { Not assessed but all o } \\
\text { Mediterranean-based } \\
\text { diet }\end{array}$ & $\begin{array}{l}\text { No antibiotics } \\
\text { for } 3 \text { months }\end{array}$ \\
\hline $\begin{array}{l}\text { Berding et al. [29], } \\
\text { 2018, USA }\end{array}$ & 26 & - & 32 & $2-7$ & No comment & $\begin{array}{l}\text { Adapted GI } \\
\text { Severity Index }\end{array}$ & $\begin{array}{l}\text { Questionnaire; } \\
\text { 3-day food diary; } \\
\text { Youth and Adolescent } \\
\text { Food Frequency } \\
\text { Questionnaire }\end{array}$ & $\begin{array}{l}\text { No antibiotics } \\
\text { for } 3 \text { months }\end{array}$ \\
\hline $\begin{array}{l}\text { Coretti et al. [22], } \\
\text { 2018, Italy }\end{array}$ & 11 & - & 14 & $2-4$ & $\begin{array}{l}\text { DSM-V, ADOS } 2 \\
\text { and ADI-R. Griffiths } \\
\text { Mental Development } \\
\text { Scales, Vineland } \\
\text { Adaptive Behaviour } \\
\text { Scales and CARS }\end{array}$ & $\begin{array}{l}\text { Rome III questionnaire, } \\
\text { Italian Version. } \\
\text { Excluded chronic } \\
\text { diseases of the GI } \\
\text { or respiratory tract }\end{array}$ & 3 days diary & $\begin{array}{l}\text { No antibiotics } \\
\text { for } 4 \text { weeks }\end{array}$ \\
\hline
\end{tabular}


Table 2. (continued)

\begin{tabular}{|c|c|c|c|c|c|c|c|c|}
\hline \multirow{2}{*}{$\begin{array}{l}\text { Study by year of } \\
\text { publication, Country }\end{array}$} & \multirow[t]{2}{*}{ ASD } & \multicolumn{2}{|l|}{ Control } & \multirow[t]{2}{*}{ Age, years } & \multirow[t]{2}{*}{ ASD diagnosis } & \multirow{2}{*}{$\begin{array}{l}\text { Assessment of } \\
\text { GI symptoms }\end{array}$} & \multirow[t]{2}{*}{ Assessment of diet } & \multirow{2}{*}{$\begin{array}{l}\text { Assessment } \\
\text { of antibiotics }\end{array}$} \\
\hline & & $\begin{array}{l}\text { unaffected } \\
\text { siblings }\end{array}$ & $\begin{array}{l}\text { unrelated } \\
\text { children }\end{array}$ & & & & & \\
\hline $\begin{array}{l}\text { Kang et al. [32], } \\
2018, \text { USA }\end{array}$ & 23 & - & 21 & $4-17$ & $\begin{array}{l}\text { ATEC and } \\
\text { PDD-BI }\end{array}$ & $\begin{array}{l}\text { Questionnaire } \\
\text { and 6-GSI }\end{array}$ & Questionnaire & $\begin{array}{l}\text { No antibiotics } \\
\text { for } 1 \text { month }\end{array}$ \\
\hline $\begin{array}{l}\text { Pulikkan et al. [37], } \\
\text { 2018, India }\end{array}$ & 30 & 24 & - & $3-16$ & $\begin{array}{l}\text { DSM-V, CARS, ISAA, } \\
\text { INDT-ASD and } \\
\text { paediatric neurologists, } \\
\text { psychologists and } \\
\text { specialist nurses }\end{array}$ & No comment & $\begin{array}{l}\text { Assessed in } 7 \text { days } \\
\text { and addressed that } \\
\text { all on omnivore } \\
\text { native diet }\end{array}$ & $\begin{array}{l}\text { No antibiotics } \\
\text { for } 1 \text { month }\end{array}$ \\
\hline $\begin{array}{l}\text { Rose et al. [33], } \\
\text { 2018, USA }\end{array}$ & 50 & - & 41 & $3-12$ & $\begin{array}{l}\text { DSM IV, } \\
\text { ADI-R and ADOS }\end{array}$ & $\begin{array}{l}\text { GIH survey and } \\
\text { Rome III } \\
\text { questionnaire }\end{array}$ & Questionnaire & $\begin{array}{l}\text { No antibiotics } \\
\text { for } 1 \text { month }\end{array}$ \\
\hline $\begin{array}{l}\text { Zhang et al. [25], } \\
\text { 2018, China }\end{array}$ & 35 & - & 6 & $3-8$ & DSM-V & No comment & No comment & No comment \\
\hline $\begin{array}{l}\text { Li et al. [26], } \\
2019, \text { China }\end{array}$ & 59 & - & 30 & $2-10$ & $\begin{array}{l}\text { DSM-V, ADOS, } \\
\text { Autism Behaviour } \\
\text { Checklist }\end{array}$ & $\begin{array}{l}\text { Assessed but details } \\
\text { not provided }\end{array}$ & $\begin{array}{l}\text { Not assessed but all } \\
\text { on hospital cafeteria } \\
\text { Chinese-based diet }\end{array}$ & $\begin{array}{l}\text { No antibiotics } \\
\text { for } 3 \text { months }\end{array}$ \\
\hline $\begin{array}{l}\text { Liu et al. [23], } \\
\text { 2019, China }\end{array}$ & 30 & - & 20 & $2.5-18$ & DSM-V ICD-10 & Modified 6-GSI & No comment & $\begin{array}{l}\text { No antibiotics } \\
\text { for } 3 \text { months }\end{array}$ \\
\hline $\begin{array}{l}\text { Ma et al. [24], } \\
\text { 2019, China }\end{array}$ & 45 & - & 45 & $6-9$ & DSM-V, CARS & No comment & No comment & $\begin{array}{l}\text { No antibiotics } \\
\text { for } 3 \text { months }\end{array}$ \\
\hline $\begin{array}{l}\text { Plaza-Diaz et al. [15], } \\
2019 \text { Spain }\end{array}$ & 57 & - & 57 & $2-6$ & DSM-V, ADI-R & $\begin{array}{l}\text { Noted only } 2 \text { ASD } \\
\text { children reported } \\
\text { abdominal pain, } \\
\text { no other GI symptoms }\end{array}$ & $\begin{array}{l}\text { 24-h dietary record } \\
\text { Validated } \\
\text { semiquantitative food } \\
\text { frequency questionnaire } \\
\text { used }\end{array}$ & No comment \\
\hline $\begin{array}{l}\text { Wang et al. [28], } \\
\text { 2019, China }\end{array}$ & 92 & - & 42 & $\begin{array}{l}\text { ASD } \\
4.51 \pm 2.23 \\
\text { Control } \\
3.14 \pm 1.73\end{array}$ & DSM-V & $\begin{array}{l}\text { Rome IV criteria for } \\
\text { FGIDs }\end{array}$ & Questionnaire & No comment \\
\hline $\begin{array}{l}\text { Zhai et al. [27], } \\
\text { 2019, China }\end{array}$ & 78 & - & 58 & $\begin{array}{l}\text { ASD } \\
4.96 \pm 1.01 \\
\text { Control } \\
4.90 \pm 0.97\end{array}$ & $\begin{array}{l}\text { DSM-V, } \\
\text { ICD-10, } \\
\text { ATEC }\end{array}$ & No comment & No comment & $\begin{array}{l}\text { No antibiotics } \\
\text { for } 1 \text { month }\end{array}$ \\
\hline \multicolumn{9}{|c|}{ Studies using intestinal biopsy samples } \\
\hline $\begin{array}{l}\text { Williams et al. [31], } \\
\text { 2011, USA }\end{array}$ & 15 & - & 7 & $3-5$ & $\begin{array}{l}\text { DSM-IV-TR. } \\
\text { Confirmed by } \\
\text { ADI-R }\end{array}$ & $\begin{array}{l}\text { Questionnaires and } \\
\text { standardised data } \\
\text { collection forms }\end{array}$ & No comment & $\begin{array}{l}\text { Questionnaires } \\
\text { and } \\
\text { standardized } \\
\text { data collection } \\
\text { forms on } \\
\text { medication use }\end{array}$ \\
\hline $\begin{array}{l}\text { Williams et al. [21], } \\
\text { 2012, USA }\end{array}$ & 15 & - & 7 & $3-5$ & $\begin{array}{l}\text { DSM-IV-TR. } \\
\text { Confirmed by } \\
\text { ADI-R }\end{array}$ & $\begin{array}{l}\text { Questionnaires and } \\
\text { standardised data } \\
\text { collection forms }\end{array}$ & No comment & No comment \\
\hline $\begin{array}{l}\text { Kushak et al. [17], } \\
\text { 2017, USA }\end{array}$ & 21 & - & 19 & $\begin{array}{l}\text { ASD } \\
14.43 \pm 1.07 \\
\text { Control } \\
16.05 \pm 1.25\end{array}$ & DSM-IV & $\begin{array}{l}\text { All had GI symptoms } \\
\text { and data presented } \\
\text { but unclear how } \\
\text { ascertained }\end{array}$ & $\begin{array}{l}\text { Dietary data presented } \\
\text { but unclear how } \\
\text { ascertained }\end{array}$ & No comment \\
\hline $\begin{array}{l}\text { Luna et al. [18], } \\
\text { 2017, USA }\end{array}$ & 14 & - & 21 & $3-18$ & ADOS & $\begin{array}{l}\text { Rome III } \\
\text { questionnaire }\end{array}$ & No comment & $\begin{array}{l}\text { No antibiotics } \\
\text { for } 3 \text { months }\end{array}$ \\
\hline
\end{tabular}

ADI-R, Autism Diagnostic Interview-Revised; ADOS, Autistic Diagnostic Observation Schedule; ASD, autistic spectrum disorder; ATEC, Autism Treatment Evaluation Checklist; CARS, Childhood Autism Rating Scale; CF, casein free; DSM-IV-TR/V, Diagnostic and Statistical Manual of Mental Disorders, editions IV Text Revision/V; FGID, functional gastrointestinal disorder; GI, gastrointestinal; GIH, gastrointestinal history; GF, gluten free; ICD-10, International Classification of Diseases, 10th revision; INDT-ASD, INCLEN Diagnostic Tool for autism spectrum disorder; ISAA, Indian Scale for Assessment of Autism; M-CHAT, Modified Checklist for Autism in Toddlers; PARS, Pervasive Developmental Disorders Autism Society Japan Rating Scale; PDD-BI, Pervasive Developmental Disorder Behaviour Inventory; PDD-NOS, pervasive developmental disorder not otherwise specified; 6-GSI, 6-item gastrointestinal severity index. 
Table 3. Differences in composition of microbiota by the type of bacterial detection method

Study (by year of publication) Analysis method Differences in gut microbiota

Studies of the gut microbiota and ASD using pyrosequencing only

Finegold et al. [38], 2010 BTEFAP Higher microbial diversity in ASD

Bacteroidetes phyla at high levels in severely autistic group

Firmicutes phyla predominant in control group

Desulfovibrio species and Bacteroides vulgatus species higher in ASD

Reduced populations of the Bifidobacterium genus in severely autistic group

\begin{tabular}{lll}
\hline Gondalia et al. [34], 2012 & bTEFAP & No significant difference in the bacterial composition \\
\hline De Angelis et al. [35], 2013 & bTEFAP & Higher microbial diversity in ASD \\
& 16S rRNA (active & Total and active Firmicutes lower in ASD \\
& bacteria) and & Bacteroidetes highest in ASD \\
& 16S rDNA & Caecalibacterium and Ruminococcus genera highest in PDD-NOS and controls \\
& (total bacteria) & Bacteroidetes genera, Alistipes and Akkermansia species highest in PDD-NOS or ASD \\
& Sutterellaceae and Enterobacteriaceae family higher in ASD \\
& Bifidobacterium species decreased in ASD
\end{tabular}

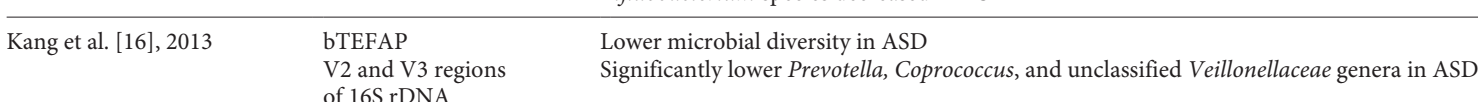

Inoue et al. [30], 2016 $\quad \begin{aligned} & \text { Illumina Miseq } \\ & \text { desktop sequencer }\end{aligned} \quad$ Significantly higher Faecalibacterium and lower abundance of Blautia genera in ASD

desktop sequencer

V3 and V4 regions

of $16 \mathrm{~S}$ rRNA

Kushak et al. [17], $2017 \quad$ bTEFAP No differences in microbial diversity

Burkholderia genus more abundant and Neisseria genus less abundant in ASD

Decrease in abundance of 2 Bacteroides species (Bacteroides vulgatus and an unknown Bacteroides species) and Escherichia coli in ASD

Oscillospira, Actinomyces, Neisseria, Peptostreptococcus, and Ralstonia over-represented in ASD

Devosia, Prevotella, Bacteroides, and Streptococcus depleted in ASD

\begin{tabular}{|c|c|c|}
\hline Luna et al. [18], 2016 & $\begin{array}{l}\text { Illumina MiSeq } \\
\text { pyrosequencing } \\
\text { V1, V3 and V4 } \\
\text { regions of } 16 \mathrm{~S} \text { rRNA }\end{array}$ & $\begin{array}{l}\text { Increase in several mucosa-associated Clostridiales in ASD, except for decreases in Dorea and Blautia } \\
\text { Decrease in Sutterella in ASD } \\
\text { Terrisporobacter species associated significantly with the ASD-FGID group } \\
\text { Statistically significant increases in Faecalibacterium prausnitzii, Roseburia intestinalis, Oscillospira valericigenes, } \\
\text { and Bilophila wadsworthia in NT-FGID group }\end{array}$ \\
\hline Strati et al. [20], 2017 & $\begin{array}{l}454 \text { pyrosequencing } \\
\text { V3-V5 of } 16 S \text { rRNA } \\
\text { Amplicon-based } \\
\text { sequencing of } \\
\text { fungal ITS1 region }\end{array}$ & $\begin{array}{l}\text { Bacterial microbiota of ASD clusters apart from that of controls } \\
\text { Firmicutes/Bacteroidetes ratio increased, reduction of the Bacteroidetes in ASD } \\
\text { Reduced Prevotella in ASD, not supported by statistical analysis } \\
\text { Decrease in relative abundance of the taxa Alistipes, Bilophila, Dialister, Parabacteroides, and Veillonella in ASD } \\
\text { Increase in the taxa Collinsella, Corynebacterium, Dorea, and Lactobacillus in ASD } \\
\text { High levels of bacterial taxa belonging to Escherichia/Shigella and Clostridium cluster XVIII in ASD children } \\
\text { with constipation } \\
\text { Relative abundance of the fungal genus Candida in ASD }\end{array}$ \\
\hline Coretti et al. [22], 2018 & $\begin{array}{l}\text { Illumina MiSeq } \\
\text { pyrosequencing } \\
\text { V3-V4 regions of } \\
\text { the } 16 \mathrm{~S} \text { rRNA }\end{array}$ & $\begin{array}{l}\text { Reduction of Actinobacteria and significant increase in Bacteroidetes and Proteobacteria in ASD } \\
\text { Bacteroidetes/Firmicutes ratio significantly higher in ASD } \\
\text { At family level Actinomycetaceae, Coriobacteriaceae, Bifidobacteriaceae, Gemellaceae and Streptococcaceae were } \\
\text { significantly reduced in ASD }\end{array}$ \\
\hline Kang et al. [32], 2018 & $\begin{array}{l}454 \text { 16S rRNA } \\
\text { pyrosequencing }\end{array}$ & $\begin{array}{l}\text { Lower microbial diversity and a significantly different gut microbiota in ASD } \\
\text { Prevotella genus significantly reduced and Coprococcus genus had marginally lower relative abundance in ASD } \\
\text { Relative abundance of phylotypes most closely related to Faecalibacterium (F.prausnitzii) and Haemophilus (H. } \\
\text { parainfluenzae) were significantly lower in ASD }\end{array}$ \\
\hline Pulikkan et al. [37], 2018 & $\begin{array}{l}\text { NextSeq500 Illumina } \\
\text { pyrosequencing } \\
\text { V3 region of } \\
16 \text { S rRNA }\end{array}$ & $\begin{array}{l}\text { Microbial diversity of the ASD group was similar to controls } \\
\text { Increased proportion of Firmicutes in ASD } \\
\text { Differences seen in the microbiome composition of children with ASD irrespective of GI symptoms } \\
\text { Higher relative abundance of Prevotellaceae in controls, higher abundance of Veillonelleaceae in the ASD } \\
\text { Significantly higher relative abundance of Lactobacillaceae, Bifidobacteraceae and Veillonellaceae in ASD } \\
\text { Higher relative abundance of genera Bifidobacterium, Lactobacillus, Megasphaera and Mitsuokella in ASD } \\
\text { The most prominent variation was shown by Lactobacillus genus, which was observed to be } 32 \text {-fold higher in ASD } \\
\text { Phylogenetic plot of the taxa of discriminatory OTUs displayed an abundance of Prevotella from family Prevotellaceae, } \\
\text { Faecalibacterium from family Clostridiaceae, and Roseburia from family Lachnospiraceae in healthy children } \\
\text { Ruminococcus from family Ruminococcaceae, Coprococcus, and Butyrivibrio from family Lachnospiraceae, and Klebsiella } \\
\text { from family Enterococcaceae were found abundant in ASD }\end{array}$ \\
\hline Rose et al. [33], 2018 & $\begin{array}{l}\text { Illumina MiSeq } \\
\text { pyrosequencing } \\
\text { V3-V4 regions of } \\
\text { the } 16 \mathrm{~S} \text { rRNA }\end{array}$ & $\begin{array}{l}\text { Increased Bacteriodaceae, Lachnospiraceae, Ruminococcaceae and Prevocellaceae in ASD children with GI symptoms } \\
\text { compared to control children with GI symptoms } \\
\text { No difference between the groups in those without GI symptoms }\end{array}$ \\
\hline
\end{tabular}


Table 3. (continued)

\begin{tabular}{|c|c|c|}
\hline Study (by year of publication) & Analysis method & Differences in gut microbiota \\
\hline Zhang et al. [25], 2018 & $\begin{array}{l}\text { Illumina HiSeq } \\
\text { Sequencing } \\
\text { V3-V4 regions of } \\
\text { 16S rRNA }\end{array}$ & $\begin{array}{l}\text { Bacteroidetes/Firmicutes ratio was significantly higher in ASD } \\
\text { Streptococcus, Veillonella and Escherichia significantly less abundant in ASD }\end{array}$ \\
\hline Li et al. [26], 2019 & $\begin{array}{l}\text { Illumina HiSeq } \\
\text { pyrosequencing } \\
\text { V1-V2 regions } \\
\text { of the } 16 \mathrm{~S} \text { rRNA }\end{array}$ & $\begin{array}{l}\text { Firmicutes/Bacteroidetes ratio similar in ASD and controls } \\
\text { Significant increase in the relative abundance of Proteobacteria in ASD } \\
\text { Significant increases in the relative abundance of Enhydrobacter, Chryseobacterium, Streptococcus, and Acinetobacter (at } \\
\text { the genus level), as well as Acinetobacter rhizosphaerae and Acinetobacter johnsonii (at the species level), in addition to a } \\
\text { significant reduction in Prevotella melaninogenica (at the species level) in ASD }\end{array}$ \\
\hline Lui et al. [23], 2019 & $\begin{array}{l}\text { Illumina MiSeq } \\
\text { Sequencing } \\
\text { V3-V4 regions of } \\
\text { 16S rRNA }\end{array}$ & $\begin{array}{l}\text { Composition of the ASD gut microbiota was different from controls } \\
\text { Firmicutes significantly decreased and Acidobacteria considerably increased in ASD } \\
\text { Veillonellaceae and Enterobacteriaceae increased in ASD, Ruminococcaceae, Streptococcaceae, Peptostreptococcaceae and } \\
\text { Erysipelotrichaceae significantly decreased } \\
\text { Significant increase of taxa Veillonellaceae and significant decrease of Erysipelotrichaceae in ASD } \\
\text { Megamonas was increased in ASD, Eubacterium and Lachnospiraceae-NC2004-group genera increased in controls }\end{array}$ \\
\hline Ma et al. [24], 2019 & $\begin{array}{l}\text { Illumina HiSeq } \\
\text { Sequencing } \\
\text { V3-V4 regions of } \\
\text { 16S rRNA }\end{array}$ & $\begin{array}{l}\text { Firmicutes/Bacteroidetes ratio not significantly different between ASD and controls } \\
\text { Differences at the family level did not reach statistical significance except for Acidaminococcaceae } \\
\text { No significant group difference was found in the relative abundance of microbiota at the class and order level } \\
\text { At the genera level, Bacteroides constituted the most abundant genus in both ASD and controls, but with no significant } \\
\text { difference. Lachnoclostridium, Tyzzerella subgroup 4, Flavonifractor and unidentified Lachnospiraceae less abundant in } \\
\text { ASD } \\
\text { At the species level, Clostridium clostridioforme more abundant in ASD }\end{array}$ \\
\hline Plaza-Diaz et al. [15], 2019 & $\begin{array}{l}\text { Illumina MiSeq } \\
\text { Sequencing } \\
\text { V3-V4 regions of } \\
\text { 16S rRNA }\end{array}$ & $\begin{array}{l}\text { Actinobacteria and Proteobacteria phyla higher in ASD } \\
\text { At class level, Actinobacteria, Bacilli, Erysipelotrichi and Gammaproteobacteria were higher in ASD } \\
\text { Bacillaceae, Bifidobacteriaceae, Corynebacteriaceae, Desulfohalobiaceae, Enterobacteriaceae, Enterococcaceae, } \\
\text { Erysipelotrichaceae, Fusobacteriaceae, Microbacteriaceae and Thermoactinomycetaceae were significantly higher in ASD, } \\
\text { Lachnospiraceae was lower in ASD } \\
\text { At genus and species levels, Bacillus, Bifidobacterium, Butyrivibrio, Enterococcus, Hespellia, Prevotella, Clostridium } \\
\text { bolteae, and Clostridium difficile significantly higher in ASD }\end{array}$ \\
\hline Wang et al. [28], 2019 & $\begin{array}{l}\text { Illumina Hiseq } 4000 \\
\text { sequencer, } \\
\text { shotgun metagenome } \\
\text { sequencing }\end{array}$ & $\begin{array}{l}\text { Significantly lower species richness in ASD children } \\
\text { Significantly higher levels of the phylum Actinobacteria in ASD } \\
11 \text { taxons were significantly higher ASD: including } 3 \text { Clostridium taxons, } 2 \text { Eggerthella taxons, and } 2 \text { Klebsiella taxons } \\
8 \text { taxons were significantly lower ASD: Bacteroides vulgatus, Betaproteobacteria, Campylobacter jejuni subsp. jejuni } \\
81-176, \text { Campylobacter jejuni subsp. jejuni ICDCCJ07001, "Candidatus Chloracidobacterium thermophilum B", } \\
\text { Coraliomargarita akajimensis DSM 45221, Proteus mirabilis, and HI4320 Spirochaeta thermophila DSM } 6192\end{array}$ \\
\hline Zhai et al. [27], 2019 & $\begin{array}{l}\text { Illumina MiSeq } \\
\text { Sequencing } \\
\text { V3-V4 regions of } \\
\text { 16S rRNA }\end{array}$ & $\begin{array}{l}\text { The gut microbiota diversity of ASD children was significantly higher } \\
\text { The ratio of Bacteroidetes to Firmicutes showed a significant increase in ASD } \\
\text { ASD children had a significant increase in nine genera: Bacteroides, Parabacteroides, Sutterella, Lachnospira, Bacillus, } \\
\text { Bilophila, Lactococcus, Lachnobacterium and Oscillospira }\end{array}$ \\
\hline \multicolumn{3}{|c|}{ Studies of the gut microbiota and ASD using pyrosequencing and $q P C R$} \\
\hline Williams et al. [31], 2011 & $\begin{array}{l}\text { qPCR and } 454 \\
\text { pyrosequencing } \\
\text { V2 of } 16 \mathrm{~S} \text { rRNA }\end{array}$ & $\begin{array}{l}\text { Lower abundance of Bacteroidetes in autistic children } \\
\text { Increased Firmicutes/Bacteroidetes ratio in autistic children } \\
\text { Increased Clostridiales levels in ASD, largely attributable to increases in Lachnospiraceae and Ruminococcaceae families } \\
\text { Elevated levels of Betaproteobacteria, primarily due to presence of Alcaligenaceae family }\end{array}$ \\
\hline Williams et al. [21], 2012 & $\begin{array}{l}\text { qPCR and } 454 \\
\text { pyrosequencing } \\
\text { V2 region of the } \\
16 S \text { rRNA }\end{array}$ & $\begin{array}{l}\text { Sutterella species (S. stercoricanis and S. wadsworthensis) present in ASD children with gastrointestinal symptoms but } \\
\text { completely absent in controls with gastrointestinal symptoms }\end{array}$ \\
\hline Son et al. [36], 2015 & $\begin{array}{l}\text { qPCR and Illumina } \\
\text { Miseq pyrosequencing } \\
\text { V1V2 and V1V3 } \\
\text { regions of } 16 \mathrm{~S} \text { rRNA }\end{array}$ & $\begin{array}{l}\text { No significant difference in diversity or overall microbial composition } \\
\text { Increased relative abundance of Chloroplast genus in ASD } \\
\text { No differences in Sutterella, Prevotella and total Bacteroidetes groups in qPCR analysis }\end{array}$ \\
\hline Berding et al. [29], 2018 & $\begin{array}{l}\text { qPCR and Illumina } \\
\text { Miseq pyrosequencing } \\
\text { V3-V4 regions of } \\
\text { 16S rRNA }\end{array}$ & $\begin{array}{l}\text { Lower abundance of Bacteroidetes but higher abundance of Firmicutes in ASD } \\
\text { The abundance of Clostridiales higher and abundance of Streptophyta lower in ASD } \\
\text { At a family level, significantly higher abundance of Coriobacteriaceae, Clostridiaceae and Peptostreptococcaceae but lower } \\
\text { abundance of Rikenellaceae in ASD } \\
\text { At a genera level, increased abundances of Clostridiaceae Clostridium, SMB53, Blautia, and Roseburia and decreased } \\
\text { abundances of Butyricimonas, Butyrivibrio, Faecalibacterium, Dialister, and Bilophila in ASD } \\
\text { Bifidobacterium and C. perfingens determined by qPCR higher in controls }\end{array}$ \\
\hline \multicolumn{3}{|c|}{ Studies of the gut microbiota and ASD using qPCR only } \\
\hline Song et al. [19], 2004 & qPCR & Clostridium bolteae, Clostridium clusters I and XI significantly elevated in ASD \\
\hline Wang et al. [40], 2011 & qPCR & $\begin{array}{l}\text { Lower relative abundances of Bifidobacterium and Akkermansia muciniphila genus in ASD } \\
\text { Elevated relative numbers of } B \text {. fragilis group in ASD children experiencing FGIDs }\end{array}$ \\
\hline
\end{tabular}


Table 3. (continued)

\begin{tabular}{|c|c|c|}
\hline Study (by year of publication) & Analysis method & Differences in gut microbiota \\
\hline Wang et al. [41], 2013 & $\mathrm{qPCR}$ & $\begin{array}{l}\text { Sutterella elevated in ASD } \\
\text { Ruminococcus torques higher in ASD children with FGID }\end{array}$ \\
\hline Tomova et al. [39], 2015 & qPCR & $\begin{array}{l}\text { Bacteroidetes/Firmicutes ratio decreased in ASD } \\
\text { Lactobacillus, Desulfovibrio and Clostridium cluster l elevated in ASD }\end{array}$ \\
\hline \multicolumn{3}{|c|}{ Studies of the gut microbiota and ASD using FISH } \\
\hline Parracho et al. [42], 2005 & FISH & $\begin{array}{l}\text { Clostridium histolyticum (Clostridium clusters I and II) higher in ASD } \\
\text { Sibling group had an intermediate level of C. histolyticum }\end{array}$ \\
\hline
\end{tabular}

[30, 35]. In contrast, in 4 studies, all participants had GI symptoms and all used mucosa-based analyses $[17,18,21$, 31]. This is unsurprising as it would be unethical to perform an endoscopy without any clinical indication. The studies that assessed GI symptoms consistently reported a significantly increased burden in autistic children. The analyses of the gut microbiota did not however always take symptoms into account. Five studies described distinct microbiota profiles in ASD with and without GI symptoms [20, 23, 33, 40, 41]. Two studies found no association $[26,28]$. The presence of GI symptoms is an important confounding factor in the study of gut microbiota and ASD.

Dietary Impact on the Microbiota in ASD

Dietary restriction is a fundamental component of ASD throughout life, and diet is also a potent driver of the individual microbiota $[29,60,61]$. Therefore, good dietary data is fundamental in understanding microbial diversity in ASD. Despite this, data on dietary patterns were collected in less than half the studies (Table 2). Most used individual questionnaires or non-validated surveys to acquire information about diet and primarily collected information on whether participants were on restricted diets (Table 2). Son et al. [36] used the Stony Brook University Medical Centre Department of Paediatrics Food Diary/Calorie Count Sheet and asked parents to record intake for 7 days prior to stool collection. They also used nutrient analysis as well as reporting the number of children on special diets [36]. Kang et al. [16] gathered information on diet patterns such as gluten-free/casein-free diets as well as information on the use of probiotics, vitamins and seafood consumption. Rose et al. [33] asked parents to report allergies, if patients were on restricted diets and if they had any specific food dislikes and foods that made symptoms worse.
Son et al. [36] reported no significant differences in microbial composition with respect to daily intake of micronutrients. No relationship was found between diet and microbial populations in the study by Parracho et al. [42]. Kang et al. [16] performed multivariate analysis and reported no significant associations between dietary intake and genus abundances. Five studies highlighted the issue of diet but did not specifically collect data [20, 22, 26, 35, 37]. De Angelis et al. [35] suggested their subjects came from the same families and so differences in diet could be excluded. Similarly, Strati et al. [20] and Li et al. [26] stated their participants were consuming a Mediterranean and Chinese diet respectively and did not comment further [22]. Pulikkan et al. [37] reported all subjects were consuming an omnivore native diet but did not provide more information. Berding et al. [29] investigated the microbiota composition in relation to feeding behaviour, nutrient and food group intake as well as dietary patterns. They found that dietary fibre negatively correlated with abundance of Clostridiales. Faecalibacterium abundance was positively correlated with fried food and negatively with fruit. They also identified that 2 distinct dietary patterns were associated with unique microbial profiles in children with ASD [29]. Similarly, differential patterns in food and microbiota were also seen in children with ASD in the study by Plaza-Diaz et al. [15]. The vast majority of studies did not collect details on diet or assess dietary impact on the gut microbiota. As diet is an important confounding factor, the extent to which diet affects the microbial composition in the ASD population remains unclear.

\section{Changes to the Microbiota in ASD}

When comparing microbial diversity of the gut microbiota in children with ASD against controls, 3 studies reported an increase in ASD [27, 35, 38], 2 reported a reduc- 
tion [16, 32], and 3 described no difference $[17,36,37]$ (Table 3). Firmicutes, Bacteroidetes and Proteobacteria were the most abundant phyla reported in all studies $(\mathrm{Ta}-$ ble 3). Bacteroidetes were increased in ASD children in 5 studies $[22,25,27,35,38]$. Three studies noted a significant increase in the Firmicutes/Bacteroides ratio due to a decrease in Bacteroidetes in ASD children [20,31,37] and 2 studies showed no difference in Bacteroidetes and Firmicutes levels $[24,26]$.

\section{Clostridia and ASD}

Within the Firmicutes phylum, increased Clostridiales levels have been reported in ASD patients in several 16S rRNA pyrosequencing studies $[15,18,24,28$, $29,31,35]$. This has also been seen with qPCR studies: 3 Clostridium clusters (I, XI, and XIVab) and one specific Clostridium species, C. bolteae, were statistically significantly higher in ASD in Song et al. [19]. A further qPCR study reported increased Clostridium cluster I in ASD [39]. Using fluorescent in-situ hybridisation, Parracho et al. [42] identified an increase in Clostridium histolyticum in stools from ASD compared to healthy controls, although unaffected siblings of ASD children also had higher levels of $C$. histolyticum than healthy controls. Strati et al. [20] showed that GI problems in ASD children were associated with high levels of Clostridia. Williams et al. [31] found that the increase in Clostridiales was largely attributable to increases in Lachnospiraceae and Ruminococcaceae. Increased Lachnospiraceae and Ruminococcaceae were also seen in ASD children with GI symptoms when compared to control children with similar symptoms in Rose et al. [33]. Pulikkan et al. [37] also noted an increase in $\mathrm{Ru}$ minococcaceae in their analysis whereas Liu et al. [23] found Ruminococcaceae to be significantly reduced in ASD.

\section{Sutterella and ASD}

Greater abundance of Sutterella has been reported in ASD children [21, 27, 35, 41]. Williams et al. [31] found elevated levels of Betaproteobacteria in ASD, reflecting the presence of Alcaligenaceae, and later described these as Sutterella species [21]. They confirmed Sutterella species in over $50 \%$ of ASD children and their complete absence in control children. Sutterella species have been identified in individuals with conditions such as IBD but also in healthy individuals [62, 63]. It is currently unclear whether they are normal commensals or pathobionts. Two other studies observed Sutterella was less abundant in ASD $[16,18]$.

ASD and Gut Microbiota
Other Bacteria Implicated in ASD

Desulfovibrio species were shown to be higher in ASD in 2 studies [38, 39]. Moreover, a strong correlation of Desulfovibrio and the severity of autism manifestations were noted [39]. Desulfovibrio species are associated with increased propionic acid (PPA) production, thought to be associated with ASD pathogenesis [64] Lactobacillus were also reported to be significantly higher in ASD in 3 studies [20, 37, 39]. Most notably, Lactobacillus genus was observed to be 32-fold higher in ASD children compared to healthy children in Pulikkan et al. [37].

Wang et al. [40] reported a lower relative abundance of Bifidobacterium in ASD compared to unrelated controls and unaffected siblings. Decreased Bifidobacteri$u m$ in ASD children was also reported in 3 other studies $[29,35,38]$, with 2 reporting a significant increase [15, 37]. Both Lactobacillus and Bifidobacterium species are commonly used in probiotic supplements [65]. Probiotic use could therefore have contributed to increased numbers of these bacteria; however, the use of probiotics at baseline was not specified in the studies concerned.

Abundance of Akkermansia muciniphila was reported decreased in ASD relative to controls in Wang et al. [40]. A. muciniphila is a mucin-degrading bacterium, usually present in large amounts in the healthy gut, thus its absence may contribute to altered mucus barrier function. In contrast, increased levels of Akkermansia have also been reported in ASD [35]. Lower levels of Prevotella genera were also noted in ASD in 4 studies $[16,17,20,32]$, although this was significant only in $3[16,17,32]$. A significant reduction in Prevotella melaninogenica species was seen in the study by Li et al. [26]. Plaza-Diaz et al. [15] reported significantly increased levels of Prevotella in ASD.

\section{Discussion}

The Brain-Gut-Microbiome axis is a concept that refers to the complex interactions between the central nervous system, GI system and the microorganisms of the GI tract. The significance of GI issues in ASD children has led to the investigation of gut microbial involvement in the disease. In this paper, we have systematically reviewed the literature and identified 28 studies assessing the microbiota in individuals with ASD compared to healthy individuals. Unfortunately, we were not able to complete a meta-analysis due to the heterogeneity of studies.

Ann Nutr Metab 2020;76:16-29

DOI: $10.1159 / 000505363$ 
Gut microbiome alterations are implicated in ASD; species which have been reported to change include Clostridium, Desulfovibrio, Lactobacillus and Sutterella. Altered gut microbial composition may cause disruption of the gut barrier, potentially allowing translocation of bacteria and their antigens, toxins and metabolites [12]. Bacterial fermentation of dietary carbohydrates normally leads to the production of short chain fatty acids (SCFAs). These are signalling molecules with a variety of functions: the most abundant SCFAs are acetic acid, butyric acid, and PPA. MacFabe [66] showed that when PPA or other SCFAs were injected into the cerebral ventricles of rats, the rats demonstrated biological, chemical, and pathologic changes that were characteristic of autism. Of note, many of the bacteria implicated in ASD, such as Clostridium and Desulfovibrio are PPA producers. Additionally, specific strains produce harmful toxins such as lipopolysaccharides, which can theoretically lead to the production of inflammatory cytokines and impair neurodevelopment $[38,67]$. Increased circulating levels of pro-inflammatory cytokines have been reported in ASD [68].

Much focus has been given to Clostridium groups in ASD, although the causal relationship remains to be proven. Bolte et al. [69] first postulated that Clostridium tetani could induce autism in 1998, although offered no mechanistic insight. Clostridiaceae synthesise metabolic products (e.g., phenols, p-cresol, certain indole derivatives) that are potentially toxic for humans. One of the first studies to speculate that disruption of the gut microbiota might contribute to autistic symptomatology was published in 2000 by Sandler et al. [70]. This small study showed improvement of autistic symptoms after oral vancomycin. Symptoms relapsed following cessation and it has been suggested this may be because Clostridium are spore-forming organisms, promoting recurrence [70]. However, of note, this study used non-validated measures to assess symptoms of autism. These findings are also yet to be replicated in further studies.

Although not a target of this review, an altered gut microbiota has also been seen in rodent models of ASD [71]. Prenatal exposure to the anticonvulsant valproate (VPA) is a risk factor for ASD and exposure to VPA in rodent models results in behavioural impairments. Studies have been reported showing altered gut microbiota, altered GI morphology and CNS inflammation following prenatal VPA treatment [71]. A study by de Theije et al. [72] showed that VPA-treated 28-day offspring had decreased abundance of Bacteroidetes phyla, mainly consisting of Bacteroidales, and increased Firmicutes micro- bial taxa, mainly consisting of Clostridiales. This is in keeping with findings from some of the studies discussed in this review.

There are numerous challenges to studying how the gut microbiota may be implicated in ASD and this is evident from the conflicting and complex results of studies conducted so far. Importantly, there is a lack of a uniform definition of ASD and the diagnostic criteria have continued to evolve over the last 15 years. Moreover, autistic spectrum disorders encompass a heterogeneous range of conditions with varying severity. The numbers of participants in the studies are often small; therefore, the chances of type 2 statistical errors cannot be disregarded. There is significant variation in the sampling methods, sites and laboratory techniques used across studies which invariably makes comparison difficult. The gut microbiota ecosystem in mucosal surfaces is fundamentally different to that of faeces; hence, the 2 are not comparable [73]. The majority of studies reported here focused on faeces. Mucosal samples are understandably difficult to obtain in this age group due to logistic and ethical limitations; however, this is an important sampling issue to keep in mind when drawing conclusions from studies. Bacteria at the mucosal surface are in close contact with the host and may have a more potent pathophysiologic role than luminal bacteria. The studies discussed used various techniques to study microbial communities. Differences may arise from various aspects: sample handling; DNA extraction; sequencing of different regions of DNA; varying coverage achieved by PCR primers; sequencing depth; and bioinformatic/statistical methods.

Additionally, not all the studies have shared important baseline information about the participants. All results need to be considered with caution, especially given the potential impact of diet, antimicrobial use and GI symptoms on the gut microbiota. Individuals with ASD are known to have specific dietary interests: they are commonly restrictive with food choices by texture, smell and taste [74]. Some individuals with ASD also follow restrictions, such as gluten-free diet, in an attempt to improve symptoms. Although popular with parents and clinicians, there is little evidence to support the use of dietary therapies for the treatment of core symptoms of ASD [75]. It has been established that diet has a significant role in the modelling of the gut microbiota [76]. Protein, fats, digestible and non-digestible carbohydrates, probiotic and polyphenols can change the microbiome [60]. Several studies have shown that a Western diet (high in animal protein and fat, low in fibre) leads to a marked decrease 
in beneficial bacteria such as Bifidobacterium and Eubacterium species [60]. In contrast, the Mediterranean diet is highly regarded as a healthy balanced diet with positive effects on inflammation and lipids, mediated by increases in Lactobacillus, Bifidobacterium and Prevotella and decreases in Clostridium [60]. Furthermore, it has been shown that dietary alterations can induce large microbial shifts, even within $24 \mathrm{~h}$ of a change [77]. To clarify the relationship between diet, gut bacteria and autism, future studies need to be carefully designed with the inclusion of validated and objective food diaries and detailed dietary histories.

Studies have shown a higher incidence of antibiotic usage in individuals with ASD, particularly because of susceptibility to infections such as otitis media [78]. In a pyrosequencing study, healthy humans were exposed to ciprofloxacin and their microbiota was assessed before and after treatment. Ciprofloxacin was found to lower the diversity of bacteria [55]. The microbial composition largely returned to pre-antibiotic state after 4 weeks; however, a few species did not return to original numbers within 6 months [55]. It is clear that antibiotics can have a significant influence on the composition of the gut microbiota and therefore may be a confounding factor in studies assessing the gut microbiota in ASD.

It is widely accepted that children with ASD have an increased prevalence of GI symptoms. Although an altered gut microbiota has been seen in children with ASD with GI symptoms, whether these changes are also seen in ASD children without GI symptoms is not clear from studies thus far. Not all studies have addressed the presence and effect of GI symptoms on ASD and microbial profiles and very few have considered them in statistical analyses, adding to the complexity of interpreting microbial outcomes.

In conclusion, ASD is an increasingly common condition that affects millions of families across the world. Studies to date have been inconsistent in their findings; however, this in part can be explained by heterogeneous populations and methods. Future studies of the gut microbiota in autism need more objective clinical assessment, consistency of case ascertainment and description. Furthermore, details regarding antibiotic use, diet and GI symptoms are key to unravelling the link between autism and an altered gut microbiota. There are several noteworthy reasons to consider that the gut microbiota may be involved in autism: the significance of GI symptoms in ASD; the apparently distinct gut microbiome of these children; and the mechanistic plausibility of bacterial products causing neurobehavioral effects. Gaining a better understanding of this important gut-brain connection may offer insights into potential diagnostic or therapeutic options and help alleviate the rising burden of ASD.

\section{Acknowledgements}

None.

\section{Statement of Ethics}

Ethical approval was not required for this work. Research was conducted ethically in accordance with the World Medical Association Declaration of Helsinki.

\section{Disclosure Statement}

N.B. and T.H.P. have nothing to disclose. G.L.H. reports receiving personal fees from Ferring from outside the submitted work. R.H. reports receiving personal fees and non-financial support from Nutricia, personal fees and non-financial support from 4D Pharma from outside the submitted work.

\section{Funding Sources}

This study did not require any funding. R.H. is supported by a personal fellowship from NHS Research Scotland.

\section{Author Contributions}

N.B.: literature search, figures, study design, data collection, data analysis, data interpretation, writing. T.H.P.: literature search, figures, data collection, data analysis, data interpretation, writing. G.L.H.: literature search, study design, data interpretation, writing. R.H.: data analysis, study design, data interpretation, writing, conception of review.
References
1 Rosenfeld CS. Microbiome Disturbances and Autism Spectrum Disorders. Drug Metab Dispos. 2015 Oct;43(10):1557-71.
2 Centers for Disease Control and Prevention [Internet]. Data \& Statistics on Autism Spec- trum Disorder [cited Jan 2019]. Available from: https://www.cdc.gov/ncbddd/autism/ data.html.
3 Tordjman S, Somogyi E, Coulon N, Kermar- rec S, Cohen D, Bronsard G, et al. Gene $\times$ En- vironment interactions in autism spectrum disorders: role of epigenetic mechanisms. Front Psychiatry. 2014 Aug;5:53. 
4 London EA. The environment as an etiologic factor in autism: a new direction for research. Environ Health Perspect. 2000 Jun;108(Suppl 3):401-4.

5 Clemente JC, Ursell LK, Parfrey LW, Knight $\mathrm{R}$. The impact of the gut microbiota on human health: an integrative view. Cell. 2012 Mar;148(6):1258-70.

6 Thursby E, Juge N. Introduction to the human gut microbiota. Biochem J. 2017 May; 474(11):1823-36

7 O'Hara AM, Shanahan F. The gut flora as a forgotten organ. EMBO Rep. 2006 Jul;7(7): 688-93.

8 Buie T, Campbell DB, Fuchs GJ 3rd, Furuta GT, Levy J, Vandewater J, et al. Evaluation, diagnosis, and treatment of gastrointestinal disorders in individuals with ASDs: a consensus report. Pediatrics. 2010 Jan;125(Suppl 1): S1-18.

9 McElhanon BO, McCracken C, Karpen S, Sharp WG. Gastrointestinal symptoms in autism spectrum disorder: a meta-analysis. Pediatrics. 2014 May;133(5):872-83.

10 Frye RE, Slattery J, MacFabe DF, Allen-Vercoe E, Parker W, Rodakis J, et al. Approaches to studying and manipulating the enteric microbiome to improve autism symptoms. Microb Ecol Health Dis. 2015 May;26:26878.

11 Gilbert JA, Krajmalnik-Brown R, Porazinska DL, Weiss SJ, Knight R. Toward effective probiotics for autism and other neurodevelopmental disorders. Cell. 2013 Dec;155(7): 1446-8.

12 Hsiao EY, McBride SW, Hsien S, Sharon G, Hyde ER, McCue T, et al. Microbiota modulate behavioral and physiological abnormalities associated with neurodevelopmental disorders. Cell. 2013 Dec;155(7):1451-63.

13 Kang DW, Adams JB, Gregory AC, Borody T, Chittick L, Fasano A, et al. Microbiota Transfer Therapy alters gut ecosystem and improves gastrointestinal and autism symptoms: an open-label study. Microbiome. 2017 Jan; $5(1): 10$.

14 Wells GA, Shea B, O'connell D, Peterson J, Welch V, Losos M, et al. [Internet] The Newcastle-Ottawa Scale [NOS] for assessing the quality of nonrandomised studies in metaanalyses [cited April 2018]. Available from: http://www.ohri.ca/programs/clinical_epidemiology/oxford.asp.

15 Plaza-Diaz J, Gomez-Fernandez A, Chueca N, Torre-Aguilar MJ, Gil A, Perez-Navero JL, et al. Autism Spectrum Disorder [ASD] with and without Mental Regression is Associated with Changes in the Fecal Microbiota. Nutrients 2019 Feb 5;11(2):e337.

16 Kang DW, Park JG, Ilhan ZE, Wallstrom G, Labaer J, Adams JB, et al. Reduced incidence of Prevotella and other fermenters in intestinal microflora of autistic children. PLoS One. 2013 Jul;8(7):e68322.

17 Kushak RI, Winter HS, Buie TM, Cox SB, Phillips CD, Ward NL. Analysis of the Duodenal Microbiome in Autistic Individuals: Association With Carbohydrate Digestion. J
Pediatr Gastroenterol Nutr. 2017 May;64(5): e110-6.

18 Luna RA, Oezguen N, Balderas M, Venkatachalam A, Runge JK, Versalovic J, et al. Distinct Microbiome-Neuroimmune Signatures Correlate With Functional Abdominal Pain in Children With Autism Spectrum Disorder. Cell Mol Gastroenterol Hepatol. 2016 Dec;3(2):218-30.

19 Song Y, Liu C, Finegold SM. Real-time PCR quantitation of clostridia in feces of autistic children. Appl Environ Microbiol. 2004 Nov; 70(11):6459-65.

20 Strati F, Cavalieri D, Albanese D, De Felice C, Donati C, Hayek J, et al. New evidences on the altered gut microbiota in autism spectrum disorders. Microbiome. 2017 Feb;5(1):24.

21 Williams BL, Hornig M, Parekh T, Lipkin WI. Application of novel PCR-based methods for detection, quantitation, and phylogenetic characterization of Sutterella species in intestinal biopsy samples from children with autism and gastrointestinal disturbances. MBio. 2012 Jan;3(1):e00261-11.

22 Coretti L, Paparo L, Riccio MP, Amato F, Cuomo M, Natale A, et al. Gut Microbiota Features in Young Children With Autism Spectrum Disorders. Front Microbiol. 2018 Dec;9:3146.

23 Liu S, Li E, Sun Z, Fu D, Duan G, Jiang M, et al. Altered gut microbiota and short chain fatty acids in Chinese children with autism spectrum disorder. Sci Rep. 2019 Jan;9(1): 287.

24 Ma B, Liang J, Dai M, Wang J, Luo J, Zhang Z, et al. Altered Gut Microbiota in Chinese Children With Autism Spectrum Disorders. Front Cell Infect Microbiol. 2019 Mar;9:40.

25 Zhang M, Ma W, Zhang J, He Y, Wang J. Analysis of gut microbiota profiles and microbe-disease associations in children with autism spectrum disorders in China. Sci Rep. 2018 Sep;8(1):13981.

26 Li N, Yang J, Zhang J, Liang C, Wang Y, Chen $\mathrm{B}$, et al. Correlation of Gut Microbiome Between ASD Children and Mothers and Potential Biomarkers for Risk Assessment. Genomics Proteomics Bioinformatics. 2019 Feb; 17(1):26-38.

27 Zhai Q, Cen S, Jiang J, Zhao J, Zhang H, Chen $\mathrm{W}$. Disturbance of trace element and gut microbiota profiles as indicators of autism spectrum disorder: A pilot study of Chinese children. Environ Res. 2019 Apr;171:501-9.

28 Wang $\mathrm{M}$, Wan J, Rong $\mathrm{H}$, He F, Wang $\mathrm{H}$, Zhou J, et al. Alterations in Gut Glutamate Metabolism Associated with Changes in Gut Microbiota Composition in Children with Autism Spectrum Disorder. mSystems. 2019 Jan;4(1):e00321-18.

29 Berding K, Donovan SM. Diet Can Impact Microbiota Composition in Children With Autism Spectrum Disorder. Front Neurosci. 2018 Jul; $12: 515$.

30 Inoue R, Sakaue Y, Sawai C, Sawai T, Ozeki $M$, Romero-Pérez GA, et al. A preliminary investigation on the relationship between gut microbiota and gene expressions in peripheral mononuclear cells of infants with autism spectrum disorders. Biosci Biotechnol Biochem. 2016 Dec;80(12):2450-8.

31 Williams BL, Hornig M, Buie T, Bauman ML, Cho Paik M, Wick I, et al. Impaired carbohydrate digestion and transport and mucosal dysbiosis in the intestines of children with autism and gastrointestinal disturbances. PLoS One. 2011;6(9):e24585.

32 Kang DW, Ilhan ZE, Isern NG, Hoyt DW, Howsmon DP, Shaffer M, et al. Differences in fecal microbial metabolites and microbiota of children with autism spectrum disorders. Anaerobe. $2018 \mathrm{Feb}$;9:121-31.

33 Rose DR, Yang H, Serena G, Sturgeon C, Ma $B$, Careaga $M$, et al. Differential immune responses and microbiota profiles in children with autism spectrum disorders and co-morbid gastrointestinal symptoms. Brain Behav Immun. 2018 May;70:354-68.

34 Gondalia SV, Palombo EA, Knowles SR, Cox SB, Meyer D, Austin DW. Molecular characterisation of gastrointestinal microbiota of children with autism (with and without gastrointestinal dysfunction) and their neurotypical siblings. Autism Res. 2012 Dec;5(6): 419-27.

35 De Angelis M, Piccolo M, Vannini L, Siragusa S, De Giacomo A, Serrazzanetti DI, et al. Fecal microbiota and metabolome of children with autism and pervasive developmental disorder not otherwise specified. PLoS One. 2013 Oct; 8(10):e76993.

36 Son JS, Zheng LJ, Rowehl LM, Tian X, Zhang Y, Zhu W, et al. Comparison of Fecal Microbiota in Children with Autism Spectrum Disorders and Neurotypical Siblings in the Simons Simplex Collection. PLoS One. 2015 Oct;10(10):e0137725.

37 Pulikkan J, Maji A, Dhakan DB, Saxena R, Mohan B, Anto MM, et al. Gut Microbial Dysbiosis in Indian Children with Autism Spectrum Disorders. Microb Ecol. 2018 Nov; 76(4):1102-14

38 Finegold SM, Dowd SE, Gontcharova V, Liu C, Henley KE, Wolcott RD, et al. Pyrosequencing study of fecal microflora of autistic and control children. Anaerobe. 2010 Aug; 16(4):444-53.

39 Tomova A, Husarova V, Lakatosova S, Bakos J, Vlkova B, Babinska K, et al. Gastrointestinal microbiota in children with autism in Slovakia. Physiol Behav. 2015 Jan;138:179-87.

40 Wang L, Christophersen CT, Sorich MJ, Gerber JP, Angley MT, Conlon MA. Low relative abundances of the mucolytic bacterium Akkermansia muciniphila and Bifidobacterium spp. in feces of children with autism. Appl Environ Microbiol. 2011 Sep;77(18):671821.

41 Wang L, Christophersen CT, Sorich MJ, Gerber JP, Angley MT, Conlon MA. Increased abundance of Sutterella spp. and Ruminococcus torques in feces of children with autism spectrum disorder. Mol Autism. 2013 Nov; $4(1): 42$. 
42 Parracho HM, Bingham MO, Gibson GR, McCartney AL. Differences between the gut microflora of children with autistic spectrum disorders and that of healthy children. J Med Microbiol. 2005 Oct;54(Pt 10):987-91.

43 American Psychiatric Association. Diagnostic and Statistical Manual of Mental Disorders. 4th Edition, Text Revision. United States: DSM-IV-TR; 2000.

44 American Psychiatric Association. Diagnostic and Statistical Manual of Mental Disorders, 5th Edition. DSM-5. United States; 2013.

45 Lord C, Rutter M, Le Couteur A. Autism Diagnostic Interview-Revised: a revised version of a diagnostic interview for caregivers of individuals with possible pervasive developmental disorders. J Autism Dev Disord. 1994 Oct;24(5):659-85.

46 Lord C, Risi S, Lambrecht L, Cook EH Jr, Leventhal BL, DiLavore PC, et al. The autism diagnostic observation schedule-generic: a standard measure of social and communication deficits associated with the spectrum of autism. J Autism Dev Disord. 2000 Jun;30(3): 205-23.

47 Schopler E, Reichler RJ, DeVellis RF, Daly K Toward objective classification of childhood autism: Childhood Autism Rating Scale (CARS). J Autism Dev Disord. 1980 Mar; 10(1):91-103.

48 Kamio Y, Yukihiro R, Adachi J. Reliability and validity of the pervasive developmental disorder [PDD]-Autism society Japan rating scale [PARS]: a behavior checklist for adolescents and adults with PDDs. Clin Psychiat. 2006; 48:485-505.

49 Robins DL, Fein D, Barton ML, Green JA. The Modified Checklist for Autism in Toddlers: an initial study investigating the early detection of autism and pervasive developmental disorders. J Autism Dev Disord. 2001 Apr 31(2):131-44.

50 Autism Researcg Institute [Internet]. Autism Treatment Evaluation checklist [ATEC] [cited September 2019]. Available from: https:// www.autism.com/ind_atec.

51 Cohen IL. Criterion-related validity of the PDD Behavior Inventory. J Autism Dev Disord. 2003 Feb;33(1):47-53.

52 Juneja M, Mishra D, Russell PS, Gulati S, Deshmukh V, Tudu P, et al.; INCLEN Study Group. INCLEN Diagnostic Tool for Autism Spectrum Disorder (INDT-ASD): development and validation. Indian Pediatr. 2014 May;51(5):359-65.

53 Mukherjee SB, Malhotra MK, Aneja S, Chakraborty S, Deshpande S. Diagnostic accuracy of Indian Scale for Assessment of Autism (ISAA) in chidren aged 2-9 years. Indian Pediatr. 2015 Mar;52(3):212-6.
54 World Health Organisation [Internet]. The ICD-10 Classification of Mental and Behavioural Disorders: Clinical Descriptions and Diagnostic Guidelines [cited September 2019]. Available from: https://apps.who.int/ iris/handle/10665/37958.

55 Dethlefsen L, Huse S, Sogin ML, Relman DA. The pervasive effects of an antibiotic on the human gut microbiota, as revealed by deep 16S rRNA sequencing. PLoS Biol. 2008 Nov; 6(11):e280

56 DiLorenzo C, Rasquin A, Forbes D, Guiraldes E, Hyams J, Staiano A, et al. Childhood functional gastrointestinal disorders: child/adolescent. In: Drossman DA, editor. Rome III: The Functional Gastrointestinal Disorders. 3rd ed. McLean (VA): Degnon Associates, Inc; 2006. pp. 723-77.

57 Koppen IJ, Nurko S, Saps M, Di Lorenzo C Benninga MA. The pediatric Rome IV criteria: what's new? Expert Rev Gastroenterol Hepatol. 2017 Mar;11(3):193-201.

58 Adams JB, Johansen LJ, Powell LD, Quig D, Rubin RA. Gastrointestinal flora and gastrointestinal status in children with autismcomparisons to typical children and correlation with autism severity. BMC Gastroenterol. 2011 Mar;11(1):22.

59 Chaidez V, Hansen RL, Hertz-Picciotto I. Gastrointestinal problems in children with autism, developmental delays or typical development. J Autism Dev Disord. 2014 May; 44(5):1117-27.

60 Singh RK, Chang HW, Yan D, Lee KM, Ucmak D, Wong K, et al. Influence of diet on the gut microbiome and implications for human health. J Transl Med. 2017 Apr;15(1):73.

61 Makki K, Deehan EC, Walter J, Bäckhed F. The Impact of Dietary Fiber on Gut Microbiota in Host Health and Disease. Cell Host Microbe. 2018 Jun;23(6):705-15.

62 Hiippala K, Kainulainen V, Kalliomäki M, Arkkila P, Satokari R. Mucosal Prevalence and Interactions with the Epithelium Indicate Commensalism of Sutterella spp. Front Microbiol. 2016 Oct; 7:1706.

63 Mukhopadhya I, Hansen R, Nicholl CE, Alhaidan YA, Thomson JM, Berry SH, et al. A comprehensive evaluation of colonic mucosal isolates of Sutterella wadsworthensis from inflammatory bowel disease. PLoS One. 2011; 6(10):e27076

64 Finegold SM. Desulfovibrio species are potentially important in regressive autism. Med Hypotheses. 2011 Aug;77(2):270-4.

65 Holzapfel WH, Haberer P, Geisen R, Björkroth J, Schillinger U. Taxonomy and important features of probiotic microorganisms in food and nutrition. Am J Clin Nutr. 2001 Feb; 73(2 Suppl):365S-73S.
66 MacFabe DF. Enteric short-chain fatty acids: microbial messengers of metabolism, mitochondria, and mind: implications in autism spectrum disorders. Microb Ecol Health Dis. 2015 May;26:28177.

67 Ashwood P, Krakowiak P, Hertz-Picciotto I, Hansen R, Pessah I, Van de Water J. Elevated plasma cytokines in autism spectrum disorders provide evidence of immune dysfunction and are associated with impaired behavioral outcome. Brain Behav Immun. 2011 Jan 25(1):40-5.

68 Goines PE, Ashwood P. Cytokine dysregulation in autism spectrum disorders (ASD) possible role of the environment. Neurotoxicol Teratol. 2013 Mar-Apr;36:67-81.

69 Bolte ER. Autism and Clostridium tetani. Med Hypotheses. 1998 Aug;5(2):133-44.

70 Sandler RH, Finegold SM, Bolte ER, Buchanan $\mathrm{CP}$, Maxwell AP, Väisänen $\mathrm{ML}$, et al. Short-term benefit from oral vancomycin treatment of regressive-onset autism. J Child Neurol. 2000 Jul;15(7):429-35.

71 Nithianantharajah J, Balasuriya GK, Franks AE, Hill-Yardin EL. Using Animal Models to Study the Role of the Gut-Brain Axis in Autism. Curr Dev Disord Rep. 2017;4(2): 28-36.

72 de Theije CG, Wopereis H, Ramadan M, van Eijndthoven T, Lambert J, Knol J, et al. Altered gut microbiota and activity in a murine model of autism spectrum disorders. Brain Behav Immun. 2014 Mar;37: 197-206.

73 Eckburg PB, Bik EM, Bernstein CN, Purdom E, Dethlefsen L, Sargent M, et al. Diversity of the human intestinal microbial flora. Science. 2005 Jun;308(5728):1635-8.

74 Ranjan S, Nasser JA. Nutritional status of individuals with autism spectrum disorders: do we know enough? Adv Nutr. 2015 Jul;6(4): 397-407.

75 Sathe N, Andrews JC, McPheeters ML, Warren ZE. Nutritional and Dietary Interventions for Autism Spectrum Disorder: A Systematic Review. Pediatrics. 2017 Jun;139(6): e20170346.

76 Scott KP, Gratz SW, Sheridan PO, Flint HJ, Duncan SH. The influence of diet on the gut microbiota. Pharmacol Res. 2013 Mar;69(1): 52-60.

77 David LA, Maurice CF, Carmody RN, Gootenberg DB, Button JE, Wolfe BE, et al. Diet rapidly and reproducibly alters the human gut microbiome. Nature. 2014 Jan;505(7484): $559-63$.

78 Niehus R, Lord C. Early medical history of children with autism spectrum disorders. J Dev Behav Pediatr. 2006 Apr;27(2 Suppl): S120-7. 